\title{
Relevansi Nilai Atas Nilai Wajar Aset dan Liabilitas Dengan Mekanisme Good Corporate Governance Sebagai Variabel Pemoderasi
}

\author{
Yusifa Pascayanti1, Aulia Fuad Rahman², Wuryan Andayani ${ }^{3}$ \\ 1,2,3Fakultas Ekonomi Dan Bisnis Universitas Brawijaya, Veteran Street, Ketawanggede, Lowokwaru, Malang, \\ 65145, East Java, Indonesia
}

Key words:

Value Relevance

Book value and profit

Fair Value

Ohlson Model (1995)

Mechanism of GCG

\begin{abstract}
A B S T R A C T
This study examines the relevance of fair value of assets and liabilities and mechanisms of good corporate governance as a moderating variable by using a sample banking companies listed in Indonesia Stock Exchange from 2012 to 2014 year. The sampling method using purposive sampling and analysis of research data using Eviews. Mechanism of Good Corporate Governance in the study visits of the independent board, institutional investors and the audit committee of the company. Furthermore, this research also investigates the value relevance of accounting information such as book value, earnings, the fair value of financial assets and liabilities with a view influence on stock prices and stock returns. Ohlson Model (1995) into the measurement model used in this study, and this study examines both the measurement model Ohlson is the pricing model and the model returns to see the consistency of the study. Significant results indicate that the book value, earnings, the fair value of assets and liabilities fair value has relevance value. So we can conclude all variables affect stock prices and stock returns. In addition, Good corporate governance mechanisms able to moderate over the value relevance of book value, earnings, fair value of financial assets and liabilities fair value.
\end{abstract}

\section{A B S T R A K}

Penelitian ini menguji relevansi nilai atas nilai wajar aset dan liabilitas dengan mekanisme Good Corporate Governance sebagai variabel pemoderasi dengan menggunakan sampel perusahaan perbankan yang terdaftar di Bursa Efek Indonesia dari tahun 2012-2014. Metode pengambilan sampel menggunakan purposive sampling dan analisis data penelitian menggunakan Eviews. Mekanisme Good Corporate Governance dalam penelitian ini dilihat dari dewan komisaris independen, investor institusional dan komite audit yang dimiliki perusahaan. Lebih lanjut, penelitian ini juga menginvestigasi relevansi nilai informasi akuntansi seperti nilai buku, laba, nilai wajar atas aset dan liabilitas keuangan dengan melihat pengaruhnya terhadap harga saham dan return saham. Model Ohlson (1995) menjadi model pengukuran yang digunakan dalam penelitian ini, dan penelitian ini berusaha mengkaji kedua model pengukuran ohlson yaitu model harga dan model return untuk melihat konsistensi penelitian. Hasil yang signifikan menunjukkan bahwa nilai buku, laba, nilai wajar aset dan nilai wajar liabilitas memiliki relevansi nilai. Maka dapat disimpulkan semua variabel berpengaruh terhadap harga saham dan return saham. Selain itu, mekanisme Good corporate governance mampu memoderasi relevansi nilai atas nilai buku, laba, nilai wajar aset keuangan, dan nilai wajar liabilitas.

\section{PENDAHULUAN}

Industri perbankan yang menjadi tonggak perekonomian negara sebagai pelaku pasar yang mendominasi transaksi intrumen keuangan mendapatkan dampak yang sangat signifikan atas penggunaan nilai wajar karena perubahan pasar finansial yang sangat dinamis. Penelitian Song et al. (2010) menemukan bahwa pengukuran nilai wajar

\footnotetext{
* Corresponding author,email address: ${ }^{1}$ a_wuryan@yahoo.com
} 
asset dan lialibilitas keuangan berdasarkan FAS 157 memiliki relevansi nilai atau dengan kata lain berpengaruh terhadap harga saham dan menemukan bahwa corporate governance mampu memoderasi relevansi nilai pengukuran nilai wajar asset dan liabilitas keuangan berdasarkan FAS 157, Relevansi nilai itu dilihat dari pengaruh pengukuran nilai wajar aset dan liabilitas keuangan terhadap harga saham. Sehingga diharapkan dalam penggunaan standar yang berbasis nilai wajar sesuai IFRS sejak tahun 2012 di Indonesia, mampu memberikan titik terang dalam menafsirkan nilai perusahaan sebagai tolak ukur bagi investor dalam pengambilan keputusannya dalam berinvestasi.

IFRS ini juga sebenarnya merupakan bagian dari penerapan good governance, karena akan meningkatkan kualitas standar akuntansi keuangan, meningkatkan kredibilitas dan kegunaan laporan keuangan, serta meningkatkan transparansi perusahaan. Ini juga berarti meningkatkan perlindungan bagi investor pasar modal karena laporan keuangan emiten yang dipubikasikan disajikan dengan standar akuntansi yang berkualitas tinggi (Daniri dan Simatupang, 2010).

Nilai wajar dinilai sebagai konsep yang paling pas dan relevan untuk penyusunan laporan keuangan sebuah perusahaan atau entitas bisnis sebab bisa menggambarkan nilai pasar yang sebenarnya (Suharto, 2009). Akuntansi nilai wajar menjadi lebih penting dalam pelaporan keuangan karena dapat memberikan informasi relevan yang berguna. Informasi yang andal akan memudahkan investor dalam menilai aturan baru yang digunakan dalam membuat keputusan (Lijing dan $\mathrm{Li}$, 2010). Pengungkapan nilai wajar baik nilai wajar aset maupun liabilitas dapat menunjukkan relevansinya dengan mempengaruhi keputusan investor maupun calon investor untuk berinvestasi. Investor tentunya dapat mengambil keputusan tersebut dengan harapan dapat mendapatkan pengembalian (return) yang lebih besar di masa yang akan datang pada investasi tersebut. Bagi seorang investor, investasi dalam sekuritas yang dipilih tentu diharapkan memberikan tingkat pengembalian (return) yang sesuai dengan resiko yang harus ditanggung oleh para investor. Bagi para investor, tingkat return ini menjadi faktor utama karena return adalah hasil yang diperoleh dari suatu investasi (Jogiyanto, 2000)

Penelitian ini merupakan pengembangan dari penelitian Song et al. (2010) yang menganalisis nilai relavan dari FAS 157 atas hierarki nilai wajar dan pengaruhnya terhadap mekanisme corporate governance. Nilai wajar ini diukur menggunakan 3 (tiga) tingkatan hierarki, yaitu tingkat (levels) 1 untuk active market, tingkat 2 untuk observable market, dan tingkat 3 untuk unobservable market. Penelitian Song et al. (2010) menemukan bahwa pengukuran nilai wajar aset dan liabilitas keuangan berdasarkan FAS 157 memiliki relevansi nilai atau dengan kata lain berpengaruh terhadap harga saham (pada level 1) dan menemukan bahwa corporate governance mampu memoderasi relevansi nilai pengukuran nilai wajar aset dan liabilitas keuangan berdasarkan FAS 157, relevansi nilai itu dilihat dari pengaruh pengukuran nilai wajar aset dan liabilitas keuangan terhadap harga saham. Perbedaan penelitian ini dengan penelitian Song et al. (2010) adalah dasar penentuan nilai wajar yang disesuaikan dengan kondisi di Indonesia yang menggunakan PSAK 55 untuk pasar aktif (active market) dengan pertimbangan bahwa aktivitas perdagangan yang aktif dilakukan melalui Bursa Efek Indonesia (BEI), karena melalui pasar aktif, semua aktivitas perusahaan dilaporkan melaui laporan keuangan yang dipublikasikan dan telah diaudit. Sementara itu untuk mekanisme corporate governance juga disesuaikan dengan pedoman corporate governance yang digunakan di Indonesia (terutama untuk perbankan), yaitu menggunakan struktur corporate governance.

\section{KERANGKA TEORI DAN HIPOTESIS}

\section{Teori Relevansi Nilai (Value Relevance Theory)}

Teori relevansi nilai merupakan turunan dari teori clean surplus. Teori ini menjelaskan bahwa nilai perusahaan tercermin pada datadata akuntansi yang terdapat pada laporan keuangan (Feltman dan Ohlson, 1995). Ohlson (1995) mengemukakan bahwa laporan laba/rugi dan neraca dapat menunjukkan nilai pasar perusahaan. Teori ini memberikan kerangka yang konsisten dengan perspektif pengukuran.

\section{Teori Sinyal (Signaling Theory)}

Menurut Jogiyanto (2000), Informasi yang dipublikasikan sebagai suatu pengumuman akan memberikan signal bagi investor dalam pengambilan keputusan investasi. Pada saat informasi diterima semua pelaku pasar terlebih dahulu menginterpretasikan dan menganalisa informasi sebagai signal baik (good news) atau signal buruk (bad news). Jika pengumuman tersebut mengandung nilai positif, maka diharapkan pasar akan bereaksi pada waktu pengumuman tersebut diterima oleh pasar. 
Teori Pengambilan Keputusan (Decision Theory )

Teori pengambilan keputusan didasari oleh konsep kepuasan (utility), yaitu bahwa utilitas merupakan jumlah dari kesenangan atau kepuasan relatif yang dicapai, dengan jumlah ini seseorang bisa menentukan meningkat atau menurunnya utilitas. Dalam teori pengambilan keputusan (Decision Theory) diharapkan semua informasi akuntansi mampu memberikan nilai investasi bagi pembacanya dan mampu menjadi tolak ukur untuk pengambilan keputusan. Berdasarkan konsep ini, setiap tindakan individu bertujuan memaksimalkan jumlah utilitas untuk mencapai kepuasaan (Pressman, 2002).

\section{Teori Keagenan (Agency Theory)}

Teori keagenan merupakan basis teori yang mendasari praktik bisnis perusahaan yang dipakai selama ini. Teori tersebut berakar dari sinergi teori ekonomi, teori keputusan, sosiologi, dan teori organisasi. Prinsip utama teori ini menyatakan adanya hubungan kerja antara pihak yang memberi wewenang yaitu investor dengan pihak yang menerima wewenang (agensi) yaitu manajer. Dijelaskan dalam Jensen dan Meckling (1976), bahwa masalah keagenan dapat terjadi dalam 2 bentuk hubungan, yaitu; (1)antara pemegang saham dan manajer, dan (2)antara pemegang saham dan kreditor.

\section{Kerangka Konseptual Penelitian}

\section{Model valuasi}

Model valuasi merupakan model yang dikembangkan oleh Ohlson (1995) yang merupakan salah satu perkembangan penting dalam penelitian akuntansi. Namun beberapa penelitian sebelumnya menemukan bahwa model ini akan mengurangi kekuatan simpulan dalam memprediksi harga maupun return jika terlalu banyak pengelompokan jumlah sampel. Model ini merupakan penjabaran konsep nilai dalam teori ekonomi neoklasik, yang menyatakan bahwa nilai perusahaan adalah sebesar nilai sekarang aliran kas bersih yang diterima pemilik.

a. Model Ohlson (1995)

Model Harga (Price model)

$P_{i, t}=\beta_{0, t}+\beta_{1, t} B_{V P S},+\beta_{1} E S_{i, t}+\beta_{1} F A_{i, t}+\beta_{1} F L_{i, t}$ $+\mu_{i, t}($ Price model $)$

$P_{i, t}$ menunjukkan harga per saham perusahaan akhir tahun fiskal $t$, dengan asumsi bahwa pada waktu tersebut harga saham telah mencerminkan semua informasi yang tersedia di pasar; $\mathrm{BVPS}_{\mathrm{i}, \mathrm{t}}$ menunjukkan nilai buku per saham (book value per share) perusahaan i pada tahun $\mathrm{t}$; EPS $_{i, t}$ menunjukkan laba per saham (earning per share) perusahaan i pada tahun t; FVA menunjukkan nilai wajar aset keuangan (fair value of financial asset) perusahaan $\mathrm{i}$ pada tahun $\mathrm{t}$; FVL menunjukkan nilai wajar liabilitas keuangan (fair value of financial liability) perusahaan i pada tahun $\mathrm{t}$.

b. Model Return (return model)

$\operatorname{Ret}_{\mathrm{i}, \mathrm{t}}=\beta_{0, \mathrm{t}}+\beta_{1, \mathrm{t}}$ BVPS $_{\mathrm{i}, \mathrm{t}}+\beta_{1} \mathrm{EPS}_{\mathrm{i}, \mathrm{t}}+$ $\beta_{1} \mathrm{FVA}_{\mathrm{i}, \mathrm{t}}+\beta_{1} \mathrm{FVL}_{\mathrm{i}, \mathrm{t}}+\boldsymbol{\mu}_{\mathrm{i}, \mathrm{t}}$ (Return model)

Ret $_{i, t}$ menunjukkan return saham perusahaan $i$ pada tahun $t$; BVPS $_{i, t}$ menunjukkan nilai buku per saham (book value per share) perusahaan i pada tahun $\mathrm{t}$; EPS $_{i, t}$ menunjukkan laba per saham (earning per share) perusahaan i pada tahun t; FVA menunjukkan nilai wajar aset keuangan (fair value of financial asset) perusahaan i pada tahun t; FVL menunjukkan nilai wajar liabilitas keuangan (fair value of financial liability) perusahaan i pada tahun $\mathrm{t}$.

\section{Instrumen Keuangan}

Instrumen keuangan (financial instrument) menurut IAS 32 adalah kontrak yang mengakibatkan timbulnya aset keuangan bagi satu entitas dan kewajiban keuangan atau instrumen ekuitas bagi entitas lainnya (mengacu pada PSAK 55).

\section{PSAK 55 (revisi 2014)}

PSAK 55 (revisi 2014) tentang Instrumen Keuangan: Pengakuan dan Pengukuran yang mengacu pada International Accounting Standards (IAS) 39 mengenai Recognition and Measurement of Financial Instruments, tidak dapat dilepaskan dari PSAK 50 (revisi 1998) tentang Instrumen Keuangan: Penyajian dan Pengungkapan yang mengacu pada IAS 32 mengenai Presentation and Disclosures of Financial Instruments.

Substansi IAS 39 dan IAS 32 sangatlah relevan bagi industri perbankan sebagai pelaku pasar yang mendominasi transaksi instrument keuangan. Oleh karenanya, tidak mengherankan jika Bank for International Settlements (BIS), sebagai lembaga internasional yang banyak merekomendasikan berbagai prinsip-prinsip kehati-hatian bagi industri perbankan. Berdasarkan Zaini (2010), substansi IAS 39 yang merupakan acuan PSAK 55 (revisi 2006) dan IAS 32 yang merupakan acuan PSAK 50 (revisi 1998): 
1. Laporan keuangan bank diharapkan dapat disajikan secara lebih wajar dan memberi informasi yang lebih bermanfaat bagi pembaca laporan keuangan.

2. Dapat mendorong proses harmonisasi penyusunan laporan keuangan dan disiplin pasar bagi perbankan.

3. Dapat mendorong bank-bank untuk menyusun laporan keuangan secara lebih wajar dan informatif serta sesuai standar internasional sehingga akan lebih siap dalam menghadapi era globalisasi.

\section{Mekanisme Corporate Governance}

Pengukuran nilai wajar mempengaruhi perilaku oportunistik manajer, namun mekanisme corporate governance yang kuat memiliki potensi untuk mengurangi masalah perilaku oportunistik manajer tersebut (Song et al., 2010). Hal ini diperkuat oleh Aboody et al., (2006) yang menemukan bahwa perusahaan dengan mekanisme corporate governance yang lemah akan memperlemah estimasi nilai opsi perusahaan. Mekanisme corporate governance dalam penelitian in digunakan untuk memoderasi nilai wajar dengan harga saham dan return saham mengacu pada Song et al. (2010), yang menemukan bahwa pengukuran nilai wajar asset dan lialibiltas keuangan memiliki relevansi nilai atau dengan kata lain berpengaruh terhadap harga saham.

\section{Kerangka Konseptual Penelitian}

Informasi akuntansi yang lengkap, akurat serta tepat waktu memberikan peluang bagi investor untuk mengambil keputusan secara rasional sehingga mencapai hasil sesuai yang diharapkan (Sembiring, 2005; Landsman, 2007; Suwarjono). Penerapan nilai wajar akan menguntungkan perekonomian Indonesia sebab, tanpa nilai wajar, aset-aset perekonomian nasional, baik yang dimiliki swasta maupun pemerintah, selama ini dinilai terlalu rendah, jauh lebih rendah dari nilai sewajarnya (Yusuf, 2010).

Penelitian ini akan menguji relevansi nilai atas nilai wajar aset dan liabilitas sesuai PSAK 55 dengan mekanisme corporate governance sebagai variabel moderasi.Dimana pengukuran nilai wajar bertujuan untuk mencapai harga dengan transaksi yang wajar terjadi antar pelaku pasar pada tanggal pengukuran. Nilai wajar atas aset dan liabilitas dalam laporan keuangan sesuai PSAK 55 digunakan untuk pengambilan keputusan mengenai instrumen keuangan dan harga pasar saham melalui mekanisme corporate governance.

\section{Pengembangan Hipotesis}

Berdasarkan masalah penelitian yang telah disampaikan dalam rumusan masalah, maka dikembangkan hipotesis sebagai berikut.

\section{Hubungan Relevansi Nilai Buku dengan Harga Saham}

Nilai buku merupakan informasi yang berasal dari neraca, mencerminkan nilai bersih yang berasal dari perusahaan dan laba merupakan informasi yang berasal dari laporan laba rugi yang mencerminkan hasil operasional perusahaan dalam mengelola sumber daya yang dimiliki. Namun pada penilitian (Carnevale et Cal, 2009., Lev dan Zarowin 1999., Collins et al 1997) menemukan bahwa nilai buku dan laba mampu merefleksikan harga saham (memiliki explanatory power atas nilai pasar saham) dibantah dengan penelitian Lev dan Zarowin (1999) menemukan bahwa kebermamfaatan informasi akuntansi, khususnya laba, arus kas dan nilai buku semakin menurun

Pada penelitian Indra dan Syam (2004) menyimpulkan bahwa koefisien respon $R^{2}$ nilai buku (BVPS) mengalami peningkatan dan secara signifikan berpengaruh terhadap harga saham. Penelitian Collins (1999) menyatakan bahwa jika perusahaan rugi, pasar bersikap seolah-olah percaya pada nilai buku ekuitas sehingga terjadi penurunan slope koefisien laba yang merugi dikarenakan pergeseran relevansi nilai laba akuntansi ke nilai buku ekuitas

Selain itu khusus kondisi di Indonesia, menunjukkan bahwa rasio harga nilai buku (rasio PBV) dapat digunakan untuk mengidentifikasi saham mana yang harganya wajar, terlalu rendah (undervalued) dan terlalu tinggi (overvalued) dengan demikian dapat digunakan sebagai dasar untuk menyusun strategi investasi (Utama dan Santosa, 1998).

H1.a : Nilai buku berpengaruh positif terhadap harga saham (price model).

\section{Hubungan Relevansi Nilai Buku dengan Return Saham}

Nilai buku (book value) per lembar saham menunjukkan aktiva bersih (net assets) per lembar saham yang dimiliki oleh pemegang saham. Nilai buku per lembar saham (Book Value Per Share) dapat mencerminkan berapa besar jaminan yang akan diperoleh oleh pemegang saham apabila perusahaan penerbit saham (emiten) dilikuidasi. Nilai buku menunjukkan aktiva bersih yang dimiliki perusahaan yang dapat dikelola untuk menghasilkan laba.

Konsep nilai buku yang paling sering digunakan yaitu sebagai nilai harga per saham dengan membandingkan nilai ekuitas dengan 
jumlah saham yang beredar pada tanggal neraca. Namun, bagi seorang investor, investasi dalam sekuritas yang dipilih tentu diharapkan memberikan tingkat pengembalian (return) yang sesuai dengan resiko yang harus ditanggung oleh para investor. Bagi para investor, tingkat return ini menjadi faktor utama karena return adalah hasil yang diperoleh dari suatu investasi (Jogiyanto, 2000). Maka untuk menguji apakah nilai buku mampu berpengaruh pada return saham, hipotesis yang muncul adalah :

H1.b :Nilai buku berpengaruh positif terhadap return saham (return model).

\section{Hubungan Relevansi Laba dengan Harga Saham}

Laba tahunan memiliki kandungan informasi, apabila laba tahunan memiliki kandungan informasi, apabila pengumuman laba akan menyebabkan perubahan reaksi investor dalam pengambilan keputusannya dalam investasi dan terhadap distribusi aliran kas dimasa yang akan datang, yang akan menyebabkan perubahan harga saham. Perubahan harga saham disekitar tanggal pengumuman diharapkan lebih besar jika dibandingkan dengan perubahan harga saham diluar tanggal pengumuman. Informasi laba akuntansi mempunyai pengaruh positif dengan harga saham (Rahman, 2008). Hal ini mengindentifikasikan bahwa investor menggunakan informasi laba dan mampu menilai kinerja perusahan pada periode pengamatan.

Didukung Pinasti (2004) dalam penelitiannya, harga saham merupakan salah satu faktor alasan investor untuk mengambil keputusan investasinya, dengan didasarkan pada laba per saham yang merupakan kekuatan laba perusahaan ketika menghitung per lembar saham yang akan mempengaruhi ekuitas perusahaan. Investor akan cenderung melirik laba perusahaan yang tergolong baik untuk memberikan sinyal positif dalam pengambilan keputusan ekonominya.

H2.a : Nilai laba berpengaruh positif terhadap harga saham (price model).

\section{Hubungan Relevansi Laba dengan Return Saham}

Lev dan Zarowin (1995) yang meneliti kegunaan informasi laba dan arus kas operasi dibandingkan dengan total informasi yang ada di pasar dengan periode pengamatan 20 tahun (19771996). Penemuannya mengindikasikan bahwa hubungan cross sectional model return yaitu hubungan pelaporan laba akuntansi dan arus kas operasi dengan return saham mengalami penurunan selama 20 tahun masa pengamatan. Model Ohlson (1995) menggambarkan hubungan laba dan nilai buku ekuitasnya dengan harga pasar saham peusahaan dengan dua model penilaian, dengan harga saham (price model) dan return saham (return model). Karena laba (Earning per share) menunjukkan hasil yang diperoleh atas pengelolaan aktiva dan mampu menunjukkan aliran kas masa depan yang dapat diberikan perusahaan terhadap investor, diharapakan mampu memprediksi return perusahaan sebagai nilai investasi masa depan.

Tujuan dari EPS adalah untuk memberikan investor sebuah indikator atas (1) nilai perusahaan dan (2) harapan dividen di masa mendatang. Masalah teori yang terbesar yang mengelilingi presentasi EPS adalah apakah informasi ini harus berdasarkan pada sejarah atau ramalan informasi. Badan akuntansi yang berwenang telah menetapkan bahwa EPS didasarkan pada data historis, bukan data ramalan. EPS merupakan indikator keseluruhan, yaitu nilai tunggal yang memberikan informasi tentang kinerja atau posisi keuangan perusahaan. Namun, Omran dan Ragab (2003) menemukan bahwa ada bukti relevansi nilai melalui model return. Kemudian dari penelitian tersebut Oman dan Ragab beranggapan bahwa ada hubungan yang signifikan.

H2.b : Nilai laba berpengaruh positif terhadap return saham (return model).

\section{Hubungan Relevansi Nilai Wajar aset dengan Harga Saham}

Relevansi nilai informasi akuntansi merupakan konsep yang membahas tentang berbagai makna dan ukuran yang berkenaan dengan akuntansi. Informasi akuntansi diprediksi memiliki nilai relevansi, karena informasi akuntansi secara statistik berhubungan dengan nilai pasar saham (Beaver, 2002; Rahmawati, 2005). Penelitian Song et al. (2010) menemukan bahwa pengukuran nilai wajar asset dan lialibilitas keuangan berdasarkan FAS 157 memiliki relevansi nilai atau dengan kata lain berpengaruh terhadap harga saham dan menemukan bahwa corporate governance mampu memoderasi relevansi nilai pengukuran nilai wajar asset dan lialibilitas keuangan berdasarkan FAS 157, Relevansi nilai itu dilihat dari pengaruh pengukuran nilai wajar asset dan lialibilitas keuangan terhadap harga saham. Informasi yang andal akan memudahkan investor dalam menilai aturan baru yang digunakan dalam membuat keputusan (Lijing dan Li, 2010). Lijing dan Li (2010) menemukan bahwa nilai pasar saham memiliki hubungan dengan pengukuran nilai wajar.

H3.a : Nilai wajar aset keuangan berpengaruh 
positif terhadap harga saham (price model).

\section{Hubungan Relevansi Nilai Wajar Aset dengan Return Saham}

Penerapan nilai wajar akan menguntungkan perekonomian Indonesia sebab, tanpa nilai wajar, aset-aset perekonomian nasional, baik yang dimiliki swasta maupun pemerintah, selama ini dinilai terlalu rendah, jauh lebih rendah dari nilai sewajarnya (Yusuf, 2010). Informasi akuntansi diperlukan dalam proses pengambilan keputusan oleh investor. Informasi akuntansi memiliki relevansi nilai jika mempunyai hubungan dalam memprediksi nilai pasar ekuitas (Barth et al., 2001). Ball dan Brown (2000) membuktikan bahwa informasi akuntansi bermamfaat bagi investor untuk mengestimasi nilai yang diharapkan (expected value) dari tingkat return dan tingkat risiko dari sekuritas, diperkuat dengan penelitian (Scott, 2009) yang menyebutkan bahwa pengambilan keputusan investasi oleh investor dilakukan secara rasional dalam rangka memaksimalkan utilitasnya, secara rata-rata para investor memamfaatkan informasi akuntansi keuangan sebagai pertimbangan dalam keputusan investasinya, megimplementasikan teori pengambilan keputusan (Decision Theory).s

Bagi para investor, tingkat return ini menjadi faktor utama karena return adalah hasil yang diperoleh dari suatu investasi (Jogiyanto, 2000), dan membuktikan teori sinyal (signaling theory), yang menitikberatkan pada informasi yang mampu memberikan sinyal baik (good news) atau buruk (bad news) untuk pengambilan keputusan investasi tersebut. Untuk melengkapi keterbatasan penelitian Cahyonowati dan Ratmono (2012), untuk meneruskan model penelitian dengan model return untuk konsistensi penelitian.

H3.b : Nilai wajar aset keuangan berpengaruh positif terhadap return saham (return model).

\section{Hubungan Relevansi Nilai Wajar liabilitas dengan Harga Saham}

Penilaian menggunakan nilai wajar tidak hanya meliputi aset dan instrument keuangan lainnya, melainkan juga kewajiban suatu perusahaan atau entitas bisnis, baik pada perusahaan yang bergerak di bidang keuangan maupun sektor riil yang menggunakan instrumen keuangan. Nilai wajar dinilai sebagai konsep yang paling pas dan relevan untuk penyusunan laporan keuangan sebuah perusahaan atau entitas bisnis sebab bisa menggambarkan nilai pasar yang sebenarnya (Suharto, 2009). Pengungkapan nilai wajar berdasarkan PSAK 55 terhadap aset dan liabilitas keuangan merupakan salah satu informasi penting yang dapat mempengaruhi keputusan tersebut (Song et al, 2010) dengan menerapkan teori relevansi nilai (value relevancetheory), karena menguji asosiasi antara angka-angka akuntansi dengan nilai pasar ekuitas untuk memperbaiki miss-spesifikasi dalam metodologi pengukuran basis teoritis sebelumnya. Nilai wajar liabilitas (kewajiban) keuangan memberikan nilai yang tidak signifikan terhadap nilai pasar saham, dikarenakan liabilitas yang tinggi berbanding terbalik dengan harga saham (Song et al, 2010).

H4.a : Nilai wajar liabilitas keuangan berpengaruh negatif terhadap harga saham (price model).

\section{Hubungan Relevansi Nilai Wajar liabilitas dengan Return Saham}

Cahyonowati dan Ratmono (2012) menggunakan price model dalam meneliti relevansi nilai informasi akuntansi. Mereka menelaah keterbataan dari penelitian tersebut dan menyarankan pengembangan pengujian relevansi informasi akuntansi dari menggunakan model harga (pricemodel) yang dikembangkan Ohlson (1995) dikembangkan menggunakan model return untuk menguji generalisasi temuan penelitian mereka. Sehingga untuk konsistensi penelitian, menggunakan dua model tersebut karena kedua model tersebut bersifat komplementer. Francis dan Schipper (1999) mendefinisikan relevansi nilai informasi akuntansi sebagai kemampuan angkaangka akuntansi untuk merangkum informasi yang mendasari harga saham, sehingga relevansi nilai diindikasikan dengan sebuah hubungan statistikal antara informasi keuangan dan harga atau return saham. Jika hasil prediksi terhadap harga saham tidak signifikan (Song et al, 2010), maka untuk menilai return bisa terpengaruh dengan hasil yang sebelumnya.

H4.b : Nilai wajar liabilitas keuangan berpengaruh negatif terhadap return saham (return model).

\section{Hubungan Relevansi Nilai Buku, Harga Saham, dan GCG.}

Bughsan (2005) menyatakan bahwa corporate governance diharapkan mampu menjaga proses pelaporan keuangan sehingga menghasilkan informasi yang berkualitas tinggi, meningkatkan transparansi dan kemudian menjaga keberlanjutan usaha perusahaan. Perlu diingat bahwa rasio nilai buku (book value per share), hanya efektif jika digunakan untuk menilai saham-saham pada sektor ekonomi yang sama atau perusahaanperusahaan yang bergerak di bidang yang sama. Karena aktiva bersih yang dimiliki pemilik atau 
pemegang saham dianggap mampu merefleksikan nilai perusahaan. Model persamaan relevansi nilai yang tidak mempertimbangkan peran nilai buku akan menghasilkan koefisien laba yang bias, dan nilai buku dapat meminimalkan bias tersebut (Collins et al., 1999).

H5.a. Mekanisme GCG memoderasi pengaruh nilai buku terhadap harga saham (price model)

\section{Hubungan Relevansi Nilai Buku, Return Saham, dan GCG.}

Pada penelitian Indra dan Syam (2004) menyimpulkan bahwa nilai buku (BVPS) memiliki koefisien respon $\mathrm{R}^{2}$ yang mengalami peningkatan dan secara signifikan berpengaruh positif terhadap harga saham. Dari penelitian ini diharapakan nilai buku yang berpengaruh positif dengan harga saham, mampu memprediksi return saham dengan bersamaan. Hasil yang diharapkan mampu meningkat dengan penerapan mekanisme good corporate governance dalam perusahaan, sehingga nilai dari suatu perusahaan tersebut baik. Corporate Governance adalah sesuatu tentang siapa yang mengontrol perusahaan dan mengapa mengontrol (Kaen, 2003). Informasi akuntansi yang disajikan oleh perusahaan yang memiliki GCG akan direspon lebih baik oleh investor. Perusahaan dengan mekanisme corporate governace yang lemah akan memperlemah estimasi nilai opsi perusahaan (Aboody et al., 2006). Apakah fenomena good corporate governance mampu menjelaskan bahwa mekanisme corporate governance mampu memperkuat atau memperlemah hubungan variabel independen dan dependen.

H5.b. Mekanisme GCG memoderasi pengaruh nilai buku terhadap return saham(return model)

\section{Hubungan Relevansi Nilai Laba, Harga Saham, dan GCG.}

Laba per lembar saham (EPS) merupakan laba yang dimiliki pemegang saham tiap lembar saham yang dimiliki. Informasi laba akuntansi memiliki informasi yang positif yang mempengaruhi harga saham (Indra dan Syam, 2004). Corporate governance sendiri memiliki mamfaat mengurangi agency cost, yaitu biaya yang harus ditanggung pemegang saham sebagai akibat pendelegasian wewenang kepada pihak manajemen, Mengurangi cost of capital, yaitu biaya yang harus ditanggung perusahaan akibat pengunaan sumber dana, merupakan dampak dari pengelolaan perusahaan yang baik menyebabkan tingkat bunga atas dana atau sumber daya yang dipinjam oleh perusahaan semakin kecil seiring dengan turunnya tingkat risiko perusahaan, Menciptakan dukungan para stakeholder (para pemangku kepentingan) dalam lingkungan perusahaan tersebut terhadap keberadaan perusahaan dan berbagai strategi dan kebijakan yang ditempuh perusahaan dan meningkatkan nilai saham perusahaan sekaligus dapat mengingkatkan citra perusahaan di mata public dalam jangka panjang. Berdasarkan pada peran corporate governance dalam meningkatkan informasi akuntansi, maka corporate governance mampu dimasukkan dalam model Ohlson (1995) untuk mengetahui dampaknya pada relevansi nilai laba dan nilai buku.

H6.a. Mekanisme GCG memoderasi pengaruh nilai laba terhadap harga saham (price model).

\section{Hubungan Relevansi Nilai Laba, Return Saham, dan GCG.}

Laba (EPS) menggambarkan kekayaan investor untuk setiap lembar sahamnya, sehingga dengan meningkatnya harga laba akan meningkat pula harga saham maupun return saham saat informasi akuntansi diumumkan. Mekanisme good corporate governance mampu memperkuat pengaruh variabel independen dengan dependen, karena koefisien positif menunjukkan laba dan mekanisme good corporate governance terhadap harga saham (Agusti, 2011). Diharapkan akan berpengaruh terhadap return saham sebagai refleksi pergerakan harga saham itu sendiri.

H6.b. Mekanisme GCG memoderasi pengaruh nilai laba terhadap return saham (return model).

\section{Hubungan Relevansi Nilai Wajar Aset Keuangan, Harga Saham, dan GCG.}

Landsman; Penman (2007) membuktikan asimetri informasi akuntansi antara investor dan manajer yang dapat menjadi ancaman serius bagi keandalan nilai dan faktor agency problem berhubungan dengan dewan komisaris, investor institusional dan komite audit (Anwar, 2011), yang merupakan penerapan dari teori keagenan (agency theory), yang menjelaskan hubungan keagenan adalah sebuah kontrak antara manajer (agent) dengan investor (principal).

Nilai wajar memberikan informasi yang berguna bagi investor, nilai wajar aset yang menjadi harga yang akan diterima dengan menjual suatu aset, dan mampu memperngaruhi nilai suatu perusahaan melalui pengukurannya dengan prediksi harga saham, namun nilai relevan untuk fair value berdasarkan FAS 157 kurang berpengaruh akibat lemahnya corporate governance (Song et al., 2010). Oleh sebab itu, sangat penting bagi perusahaan untuk menerapkan suatu good corporate 
governance sehingga informasi yang disajikan oleh perusahaan memiliki relevansi nilai.

H7.a. Mekanisme GCG memoderasi pengaruh nilai wajar aset keuangan terhadap harga saham (price model)

\section{Hubungan Relevansi Nilai Wajar Aset Keuangan,} Return Saham, dan GCG.

IFRS ini juga sebenarnya merupakan bagian dari penerapan good governance, karena akan meningkatkan kualitas standar akuntansi keuangan, meningkatkan kredibilitas dan kegunaan laporan keuangan, serta meningkatkan transparansi perusahaan. Ini juga berarti meningkatkan perlindungan bagi investor pasar modal karena laporan keuangan emiten yang dipubikasikan disajikan dengan standar akuntansi yang berkualitas tinggi (Daniri dan Simatupang, 2010).Bhat (2008) meneliti hubungan pengungkapan dan corporate governance dengan nilai wajar berdasarkan SFAS No. 157 dengan mengobservasi perbankan di Amerika Serikat. Hasil penelitiannya menunjukkan bahwa pengungkapan (disclosure) memiliki pengaruh langsung terhadap nilai wajar berdasarkan SFAS No. 157, sedangkan corporate governance memiliki pengaruh tidak langsung melalui mediasi pengungkapan. Aboody et al (2006) menemukan bahwa perusahaan dengan mekanisme corporate governace yang lemah akan memperlemah estimasi nilai opsi perusahaan. Dan return yang diharapkan semua pemangku kepentingan diharapkan mampu meningkat dengan tata kelola perusahaan yang baik, agar investor dan pemangku kepentingan lainnya mampu melihat profil perusahaan dengan tata kelola yang baik untuk menghasilkan return yang bagus.

H7.b. Mekanisme GCG memoderasi pengaruh nilai wajar aset keuangan terhadap return saham(return model).

\section{Hubungan Relevansi Nilai Wajar Liabilitas Keuangan, Harga Saham, dan GCG.}

Salah satu makna liabilitas keuangan adalah setiap liabilitas yang berupa kewajiban kontraktual untuk menyerahkan kas atau aset keuangan lain kepada entitas lain atau untuk mempertukarkan aset keuangan dan liabilitas keuangan dengan entitas lain, dari penjelasan ini menggambarkan nilai wajar liabilitas keuangan tidak berbanding lurus dengan nilai wajar aset keuangan terkait pengaruhnya dengan harga saham. Namun apabila dilengkapi dengan mekanisme tata kelola perusahaan dengan baik (good corporate governance), pengaruh hubungan tersebut bisa dilihat apakah mampu memperkuat atau memperlemah hubungan antara nilai wajar liabilitas dengan harga saham dan agency problem bisa dihindari (agency theory).

H8.a. Mekanisme GCG memoderasi pengaruh nilai wajar liabilitas keuangan terhadap harga saham (price model).

\section{Hubungan Relevansi Nilai Wajar Liabilitas Keuangan, Return Saham, dan GCG.}

Dalam penelitian ini mekanisme corporate governance mempengaruhi perilaku opportunistik manajer, namun mekanisme corporate governance yang kuat memiliki potensi untuk mengurangi masalah perilaku opportunistik manajer (agency theory) tersebut (Song et al, 2010). Mekanisme corporate governance yang digunakan untuk memoderasi nilai wajar dengan return saham, yang menemukan bahwa nilai wajar aset dan liabilitas keuangan memiliki relevansi nilai atau dengan kata lain berpengaruh terhadap harga saham. Dimana relevansi nilai itu dilihat dari pengaruh pengukuran nilai wajar aset dan liabilitas keuangan terhadap harga saham maupun return saham. Dengan model Ohlson (1995) akan terbukti apakah dua model penilaian (price dan return model) tentang value relevance mampu memberikan konsistensi penelitian.

H8.b. Mekanisme GCG memoderasi pengaruh nilai wajar liabilitas keuangan terhadap return saham (return model).

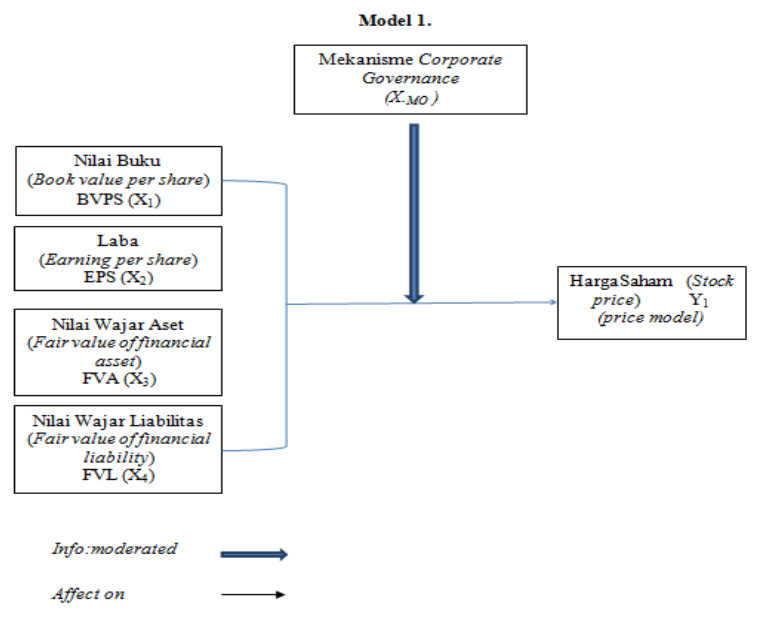




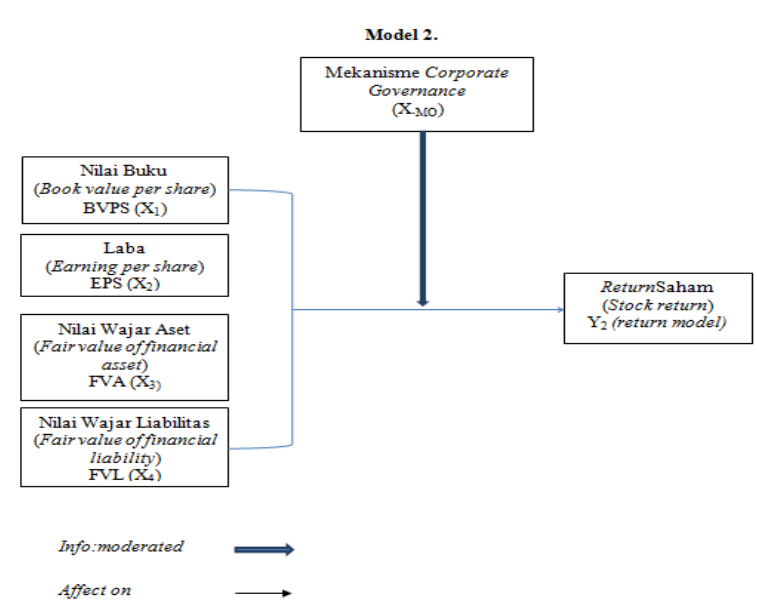

\section{METODE PENELITIAN}

Jenis penelitian ini apabila dikelompokkan sesuai dengan sifat eksplanasi ilmu adalah penelitian kausalitas. Objek penelitian ini adalah industri perbankan yang tercatat di Bursa Efek Indonesia (BEI).

Sumber data dalam penelitian ini adalah data sekunder, yang diperoleh dari laman resmi PT. Bursa Efek Indonesia yaitu www.idx.co.id dan ICMD . Data tersebut terdiri dari:

1. Data nilai buku dan laba, yang terdapat dalam laporan keuangan tahun 2012 sampai dengan 2014.

2. Data nilai wajar aset dan nilai wajar liabilitas, yang terdapat dalam laporan keuangan tahun 2012 sampai dengan 2014.

3. Data Dewan Komisaris Independen, Investor Institusional dan Komite Audit.

4. Data harga per lembar saham biasa yang diperdagangkan melalui BEI.

\section{Populasi dan Sampel \\ Populasi}

Perusahaan-perusahaan perbankan yang terdaftar di Bursa Efek Indonesia dari tahun 2012 sampai dengan 2014.

Sampel

Metode pemilihan sampel yang digunakan adalah nonprobabilitas (nonprobability) dengan pemilihan sampel bertujuan (purposive sampling).

\section{Definisi Operasional dan Pengukuran Variabel Variabel Independen}

Variabel independen dalam penelitian ini adalah Nilai buku, Laba, dan nilai wajar.

1) Nilai buku per lembar saham / book value per share (X1) yang menunjukkan aktiva bersih (net assets) yang dimiliki pemegang saham dengan memiliki satu lembar saham. Aktiva bersih adalah sama dengan total ekuitas pemegang saham, maka nilai buku per lembar saham adalah total ekuitas dibagi jumlah lembar saham yang beredar.

Nilai Buku

Per Lembar Saham $=$ Total Ekuitas

Jumlah lembar saham yang beredar

2) Laba per lembar saham / Earning per share (X2) adalah laba bersih sebelum extraordinary items dan discounted operations. Diukur dengan menggunakan :

Laba Per Lembar Saham $=\underline{L}$ aba akuntansi Jumlah lembar saham yang beredar

3) Nilai wajar. Nilai wajar (Yusuf, 2010) merupakan istilah dalam standar akuntansi, dimana aset dan kewajiban dicatatkan dalam laporan keuangan berdasarkan model revaluasi.

Nilai wajar diporksikan sebagai berikut: (Song et al., 2010)

1. Nilai wajar asset (X3) diukur menggunakan jumlah dari (a) sekuritas investasi, termasuk sekuritas yang diperdagangkan, sekuritas yang dapat dijual dan sekuritas yang telah jatuh tempo; (b) aset turunan (derivative assets); (c) pinjaman; (d) aset lainnya, termasuk investasi lainnya. Total dari keseluruhan nilai wajar aset keuangan dibagi dengan total aset perusahaan.

2. Nilai wajar liabilitas (X4) diukur menggunakan jumlah dari (a) liabilitas yang diperdagangkan; (b) kewajiban jangka panjang; (c) liabilitas turunan (derivative liabilities); (d) liabilitas lainnya termasuk deposit. Total dari nilai wajar liabilitas keuangan dibagi dengan total aset perusahaan.

\section{Variabel Dependen}

Variabel dependen dalam penelitian ini adalah harga saham dalam price model dan return saham perusahaan dalam return model model Ohlson (1995). Harga saham menunjukkan respon investor dalam pengambilan keputusan investasi terhadap informasi akuntansi dan non akuntansi.

1) Harga saham yang digunakan dalam penelitian ini adalah harga saham penutupan (closing price) setelah tanggal laporan keuangan

2) Return saham dalam penelitian ini merupakan hasil yang diperoleh dari suatu investasi. Return saham dapat berupa return saham realisasi yang sudah terjadi atau return saham 
ekspektasi yang belum terjadi tetapi diharapkan akan terjadi di masa yang akan datang (Jogiyanto, 2000).

Adapun return saham dapat dihitung dengan menggunakan rumus (Jogiyanto, 2000):

$$
R t=\frac{P_{t}-P_{t-1}}{P_{t-1}}
$$

Dimana:

Rt $\rightarrow$ Return saham pada hari ke $t$

$\mathrm{Pt} \rightarrow$ Harga penutupan saham pada hari ke $t$

Pt-1 $\rightarrow$ Harga penutupan saham pada hari ke $t-1$

\section{Variabel Pemoderasi}

Variabel pemoderasi dalam penelitian ini adalah corporate governance. Corporate governance, sebagai seperangkat aturan yang menetapkan hubungan antara pengawas, pemegang saham, pengurus, pihak kreditur, pemerintah, karyawan, serta para pemegang intern dan ekstern lainnya sehubungan dengan hak-hak dan kewajiban mereka.

Mekanisme corporate governance, yang diproksikan sebagai berikut:

1. Dewan komisaris independen, diukur menggunakan persentase anggota dewan komisaris independen dengan jumlah seluruh anggota dewan komisaris.

2. Investor institusional, diukur menggunakan persentase jumlah investor institusional.

3. Komite Audit, diukur menggunakan jumlah komite audit.

\section{Teknik Analisis Data}

Setelah melakukan pengumpulan data, tahap berikutnya adalah menganalisis data dengan menggunakan regresi dalam pengujian hipotesis. Pengujian hipotesis dilakukan dengan menggunakan program Eviews. Dengan menguji persamaan dasar yang menggunakan Model Ohlson (1995).

\section{Model Penelitian}

Model 1 (price model) digunakan untuk pengujian hipotesis dan menjawab perumusan masalahsebagai berikut :

A. Model Harga (Price model) $-\mathrm{Y}_{1}$

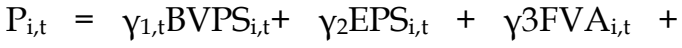
$\gamma_{4} \mathrm{FVL}_{\mathrm{i}, \mathrm{t}}+\varepsilon_{\mathrm{i}, \mathrm{t}}$ (Price model)

Keterangan:

$\mathrm{P}_{\mathrm{i}, \mathrm{t}}\left(\mathrm{Y}_{1}\right)=$ Harga saham penutupan

Desember per periode $t$

$\mathrm{\gamma}_{1}-\mathrm{\gamma}_{4, \mathrm{t}}=$ Koefisien jalur variabel

BVPSi, $\mathrm{t}=$ Book value per share periode $\mathrm{t}$

\begin{tabular}{|c|c|}
\hline $\mathrm{EPS}_{\mathrm{i}, \mathrm{t}}$ & $=$ Earning per share periode $t$ \\
\hline FVA & $=$ The fair value of financial assets \\
\hline FVL & $=$ Fair value of financial liabilities \\
\hline BC & $=$ Board of Commissioners \\
\hline II & $=$ Institutional Investors \\
\hline $\mathrm{AC}$ & $=$ The audit committee \\
\hline$\varepsilon$ & $=$ error \\
\hline
\end{tabular}

B. Model Return (Return model)- $\mathrm{Y}_{2}$

$\operatorname{Ret}_{i, \mathrm{t}}=\gamma\left(\mathrm{\gamma}_{1, \mathrm{t}} \mathrm{BPS}_{\mathrm{i}, \mathrm{t}}+\gamma_{2} \mathrm{EPS}_{\mathrm{i}, \mathrm{t}}+\gamma_{3 \mathrm{FVA}_{\mathrm{i}, \mathrm{t}}}+\right.$ $\gamma_{4} \mathrm{FVL}_{\mathrm{i}, \mathrm{t}}+\varepsilon_{\mathrm{i}, \mathrm{t}}$ (Return model)

Keterangan:

$\operatorname{Ret}_{\mathrm{i}, \mathrm{t}}\left(\mathrm{Y}_{2)} \quad=\right.$ Return saham tahunan

$\mathrm{\gamma}_{1}-\mathrm{\gamma}_{4, \mathrm{t}}=$ Koefisien jalur variabel

BVPSi, $\mathrm{t}=$ Book value per share periode $\mathrm{t}$

EPS $_{i, t}=$ Earning per share periode $t$

FVA $\quad=$ The fair value of financial assets

FVL $\quad=$ Fair value of financial liabilities

BC $=$ Board of Commissioners

II $\quad=$ Institutional Investors

AC $=$ The audit committee

$\varepsilon=$ error

C. Moderasi Model Price $-\mathrm{X}_{1 . \mathrm{MO}}$

Mekanisme corporate governance memoderasi hubungan antara nilai buku, laba, nilai wajar aset, dan nilai wajar liabilitas keuangan terhadap harga saham (price model).

$\mathrm{P}=\gamma_{1} \mathrm{BV}+\gamma_{2} \mathrm{EPS}+\gamma_{3} \mathrm{FVA}+\gamma_{4} \mathrm{FVL}+$ $\gamma_{5}\left(\mathrm{BV}^{*} \mathrm{BC}\right)+\gamma_{6}\left(\mathrm{BV}^{*} \mathrm{II}\right)+\gamma_{7}\left(\mathrm{BV}^{*} \mathrm{CA}\right)+$ $\gamma_{8}\left(\mathrm{EPSV}^{*} \mathrm{BC}\right)+\gamma_{9}\left(\mathrm{EPS}^{*} \mathrm{II}\right)+\gamma_{10}\left(\mathrm{EPS}^{*} \mathrm{CA}\right)+$ $\gamma_{11}\left(\mathrm{FVA}^{*} \mathrm{BC}\right)+\gamma_{12}\left(\mathrm{FVA}^{*} \mathrm{II}\right)+\gamma_{13}\left(\mathrm{FVA}^{*} \mathrm{CA}\right)+$ $\gamma_{14}\left(F L^{*} B C\right)+\gamma_{15}(F V L * I I)+\gamma_{16}\left(F^{*} L^{*} \mathrm{~A}\right)+\varepsilon_{i}$

\section{Moderasi Return model- $\mathrm{X}_{2 . \mathrm{MO}}$}

Mekanisme corporate governance memoderasi hubungan antara nilai buku, laba, nilai wajar aset, nilai wajar liabilitas keuangan terhadap return saham (returnmodel) .

$\mathrm{R}=\gamma_{1} \mathrm{BV}+\gamma_{2} \mathrm{EPS}+\gamma_{3} \mathrm{FVA}+\gamma_{4} \mathrm{FVL}+$ $\gamma_{5}\left(\mathrm{BV}^{*} \mathrm{BC}\right)+\gamma_{6}\left(\mathrm{BV}^{*} \mathrm{II}\right)+\gamma_{7}\left(\mathrm{BV}^{*} \mathrm{CA}\right)+$ $\gamma_{8}\left(\mathrm{EPSV}^{*} \mathrm{BC}\right)+\gamma_{9}\left(\mathrm{EPS}^{*} \mathrm{II}\right)+\gamma_{10}\left(\mathrm{EPS}^{*} \mathrm{CA}\right)+$ $\gamma_{11}\left(\mathrm{FVA}^{*} \mathrm{BC}\right)+\gamma_{12}\left(\mathrm{FVA}^{*} \mathrm{II}\right)+\gamma_{13}\left(\mathrm{FVA}^{*} \mathrm{CA}\right)+$ $\gamma_{14}\left(F^{*} L^{*} B C\right)+\gamma_{15}(F V L * I I)+\gamma_{16}\left(F^{*} L^{*} C A\right)+\varepsilon_{i}$

\section{ANALISIS DAN PEMBAHASAN}

Koefisien determinasinya

$\left(\mathrm{R}^{2}\right) \quad$ yang ditunjukkan dalam tabel berikut :

Tabel 3

Koefisien Determinasi $\left(\mathbf{R}^{2}\right)$ Model Saham

\begin{tabular}{lcrr}
\hline & $\begin{array}{l}\text { Saham Sebelum } \\
\text { Moderasi }\end{array}$ & $\begin{array}{l}\text { Saham } \\
\text { Moderasi }\end{array}$ & Sesudah \\
\hline Rsquare & 0,683 & 0,930 \\
\hline \multicolumn{2}{c}{ Sumber $\cdot$ Data diolah 2016} &
\end{tabular}


Berdasarkan tabel di atas diketahui bahwa $\mathrm{R}^{2}$ pada persamaan saham sebelum moderasi sebesar 0,683 atau sebesar 68,3\%. Hal ini berarti keragaman harga saham dapat dijelaskan oleh book value per share, earning per share, nilai wajar asset, dan nilai wajar liabilitas sebesar $68,3 \%$, atau dengan kata lain kontribusi book value per share, earning per share, nilai wajar asset, dan nilai wajar liabilitas terhadap harga saham sebesar $68,3 \%$, sedangkan sisanya sebesar $31,7 \%$ merupakan kontribusi dari variabel lain yang tidak dibahas dalam penelitian ini.

\section{Tabel 5}

Ringkasan Hasil Pengujian Hipotesis Parsial Model Saham

\begin{tabular}{lcccccc}
\hline \multicolumn{2}{c}{ Model } & \multicolumn{2}{c}{ Persamaan 1 } & \multicolumn{4}{c}{ Persamaan 2 } \\
& Koefisien & $\boldsymbol{t}$ & Prob. & Koefisien & $\boldsymbol{t}$ & Prob. \\
\hline $\begin{array}{l}\text { Konstan } \\
\text { ta }\end{array}$ & 0,048 & 11,159 & 0,000 & 4,418 & 4,017 & 0,000 \\
\hline BVPS & 0,001 & 2,310 & 0,024 & 0,404 & 4,239 & 0,000 \\
\hline EPS & 0,048 & 2,053 & 0,044 & 1,310 & 3,815 & 0,000 \\
\hline NWA & 1,012 & 2,936 & 0,005 & 0,136 & 2,147 & 0,035 \\
\hline NWL & $-6,330$ & $-2,416$ & 0,000 & $-1,496$ & $-3,935$ & 0,000 \\
\hline
\end{tabular}

Sumber : Data diolah 2016

Tabel 6

Koefisien Determinasi $\left(\mathbf{R}^{2}\right)$ Model Return Saham Return Saham Return Saham Sebelum Moderasi Sesudah Moderasi

\begin{tabular}{lll}
\hline Rsquare & 0,359 & 0,500 \\
\hline
\end{tabular}

Sumber : Data diolah 2016

Berdasarkan tabel di atas diketahui bahwa $\mathrm{R}^{2}$ pada persamaan return saham sebelum moderasi sebesar 0,359 atau sebesar 35,9\%. Hal ini berarti keragaman return saham dapat dijelaskan oleh book value per share, earning per share, nilai wajar asset, dan nilai wajar liabilitas sebesar 35,9\%, atau dengan kata lain kontribusi book value per share, earning per share, nilai wajar asset, dan nilai wajar liabilitas terhadap return saham sebesar 35,9\%, sedangkan sisanya sebesar 64,1\% merupakan kontribusi dari variabel lain yang tidak dibahas dalam penelitian ini.

Ringkasan Hasil Pengujian Hipotesis Parsial Model Return Saham

\begin{tabular}{lcccccc}
\hline \multirow{2}{*}{ Model } & \multicolumn{3}{c}{ Persamaan 1 } & \multicolumn{3}{c}{ Persamaan 2 } \\
& Koefisien & $\mathbf{t}$ & Prob. & Koef & $\mathbf{t}$ & Prob. \\
\hline $\begin{array}{l}\text { Konstan } \\
\text { ta }\end{array}$ & 4,458 & 10,003 & 0,000 & 0,342 & 3,433 & 0,001 \\
\hline BVPS & 0,019 & 2,313 & 0,024 & 0,008 & 2,239 & 0,028 \\
\hline
\end{tabular}

\begin{tabular}{lllllll}
\hline EPS & 0,064 & 5,524 & 0,000 & 0,009 & 2,510 & 0,014 \\
\hline NWA & 0,370 & 2,140 & 0,036 & 0,009 & 2,481 & 0,016 \\
\hline NWL & $-1,564$ & $-4,271$ & 0,000 & $-0,004$ & $-2,013$ & 0,048 \\
\hline \multicolumn{2}{c}{ Sumber : Data diolah } & 2016 & & &
\end{tabular}

Sumber : Data diolah 2016

\section{Diskusi Hasil Pengujian Hipotesis \\ Hipotesis 1 (H1.a)}

Hipotesis 1(H1.a) dalam penelitian ini diterima. Maka dapat disimpulkan terdapat pengaruh yang positif dan signifikan antara book value per share terhadap harga saham.Hal ini mengindikasikan semakin tinggi book value per sharemaka cenderung dapat meningkatkan harga saham.

Hasil penelitian ini dapat memberikan bukti bahwa rasio harga nilai buku (rasio PBV) dapat digunakan untuk mengidentifikasi saham mana yang harganya wajar, terlalu rendah (undervalued) dan terlalu tinggi (overvalued) dengan demikian dapat digunakan sebagai dasar untuk menyusun strategi investasi (Utama dan Santosa, 1998).

\section{Hipotesis 1 (H1.b)}

Hipotesis 1 (H1.b) dalam penelitian ini diterima. Maka dapat disimpulkan terdapat pengaruh yang positif dan signifikan book value per share terhadap return saham. Hal ini berarti semakin tinggi book value per sharemaka cenderung dapat meningkatkan return saham. Hasil penelitian ini dapat memberikan bukti bahwarasio harga nilai buku (rasio PBV) dapat digunakan untuk mengidentifikasireturn saham sebagai dasar untuk menyusun strategi investasi (Utama dan Santosa, 1998).

Hipotesis 2 (H2.a)

Hipotesis 2 (H2.a) dalam penelitian ini diterima. Maka dapat disimpulkan terdapat pengaruh yang positif dan signifikan antara earning per share terhadap harga saham. Hal ini berarti semakin tinggi earning per sharemaka cenderung dapat meningkatkan harga saham

Hipotesis 2 (H2.b)

Hipotesis 2 (H2.b) dalam penelitian ini diterima. Hal ini menunjukkan terdapat pengaruh yang positif dan signifikan earning per share terhadap return saham. Hal ini berarti semakin tinggi earning per share maka cenderung dapat meningkatkan return.

\section{Hipotesis 3 (H3.a)}

Hipotesis 3 (H3.a) dalam penelitian ini diterima. Maka dapat disimpulkan terdapat pengaruh yang positif dan signifikan nilai wajar asset terhadap harga saham. Hal ini berarti semakin tinggi nilai wajar asset maka cenderung 
dapat meningkatkan harga saham.

Hipotesis 3 (H3.b)

Hipotesis 3 (H3.b) dalam penelitian ini diterima. Hal ini menunjukkan terdapat pengaruh positif dan signifikan terhadap return saham. Hal ini berarti semakin tinggi nilai wajar asset maka cenderung dapat meningkatkanreturn saham.

\section{Hipotesis 4 (H4.a)}

Hipotesis 4 (H4.a) dalam penelitian ini diterima. Hal ini menunjukkan terdapat pengaruh yang negatif dan signifikan antara nilai wajar liabilitas terhadap harga saham. Hal ini berarti semakin tinggi nilai wajar liabilitas maka cenderung dapat menurunkan harga saham, meskipun penurunan tersebut tidak signifikan, karena nilai berbanding terbalik antara nilai wajar liabilitas (kewajiban) perusahaan dengan harga saham merupakan suatu hal yang sesuai dengan teori pengambilan keputusan (decision theory) yang menjelaskan bahwa seorang investor tidak akan tertarik dengan tingginya nilai kewajiban (utang) perusahaannya tanpa dilengkapi dengan nilai aset yang lebih tinggi (laba tinggi).

\section{Hipotesis 4 (H4.b)}

Hipotesis 4 (H4.b) dalam penelitian ini diterima Hal ini menunjukkan terdapat pengaruh yang negatif dan signifikan nilai wajar liabilitas terhadap return saham. Hal ini berarti semakin tinggi nilai wajar liabilitas maka cenderung dapat menurunkan return saham, karena nilai berbanding terbalik antara nilai wajar liabilitas (kewajiban) perusahaan dengan return saham merupakan suatu hal yang sesuai dengan teori pengambilan keputusan (decision theory) yang menjelaskan bahwa seorang investor tidak akan tertarik dengan tingginya nilai kewajiban (utang) perusahaannya tanpa dilengkapi dengan nilai aset yang lebih tinggi (laba tinggi.

\section{Hipotesis 5 (H5.a)}

Hipotesis 5 (H5.a) dalam penelitian ini diterima. Hal ini menunjukkan terdapat pengaruh yang positif dansignifikan book value per share terhadap harga saham. Hal ini berarti semakin tinggi book value per share maka cenderung dapat meningkatkan harga saham. Maka dapat disimpulkan bahwa mekanisme GCG mampu memoderasi adanya hubungan antara relevansi nilai buku terhadap harga saham dan memperkuat hubungannya.

Hasil penelitian ini sejalan dengan temuan yang menyatakan bahwa model persamaan relevansi nilai yang tidak mempertimbangkan peran nilai buku akan menghasilkan koefisien laba yang bias, dan nilai buku dapat meminimalkan bias tersebut (Collins et al., 1999). Maka temuan ini mendukung teori agensi (agency theory) yang menjadi acuan penelitian ini.

\section{Hipotesis 5 (H5.b)}

Hipotesis 5 (H5.b) dalam penelitian ini diterima. Hal ini menunjukkan terdapat pengaruh yang positifdan signifikan book value per share terhadap return saham. Hal ini berarti semakin tinggi book value per share maka cenderung dapat meningkatkanreturn saham,Maka dapat disimpulkan bahwa mekanisme GCG mampu memoderasi adanya hubungan antara relevansi nilai buku terhadap returnsaham dan memperkuat hubungan kedua variabel.

\section{Hipotesis 6 (H6.a)}

Hipotesis 6 (H6.a) dalam penelitian ini diterima. Hal ini menunjukkan terdapat pengaruh yang positif dan signifikan earning per share terhadap harga saham. Hal ini berarti semakin tinggi earning per share maka cenderung dapat meningkatkan harga saham. Maka dapat disimpulkan bahwa mekanisme GCG memperkuat adanya hubungan antara relevansi nilai laba terhadap harga saham dan mampu memoderasi relevansi nilai laba (earning per share) terhadap harga saham.

\section{Hipotesis 6 (H6.b)}

Hipotesis 6 (H6.b) dalam penelitian ini diterima. Hal ini menunjukkan terdapat pengaruh yang positif dan signifikan earning per share terhadap return saham. Hal ini berarti semakin tinggi earning per share maka cenderung dapat meningkatkan return saham. Jika keuntungan yang diperoleh dari investasi tersebut ternyata lebih kecil dari tingkat keuntungan yang disyaratkan, berarti hal ini menunjukkan investasi tersebut kurang menarik, sehingga dapat menyebabkan turunnya return saham tersebut, namun laba yang tinggi mampu menarik minat para investor karena kebanyakan seorang investor hanya melihat keberhasilan perusahaan melalui laba dilengkapi dengan tata kelola perusahaan yang baik (good corporate governance) maka mampu memperkuat keberhasilan suatu perusahaan tersebut dan meyakinkan investor untuk berinvestasi. Maka dapat disimpulkan bahwa mekanisme GCG memperkuat adanya hubungan antara relevansi nilai laba terhadap return saham dan mampu memoderasi relevansi nilai laba (earning per share) terhadap return saham.

\section{Hipotesis 7 (H7.a)}

Hipotesis 7 (H7.a) dalam penelitian ini diterima Hal ini menunjukkan terdapat pengaruh 
yang positif dan signifikan nilai wajar asset terhadap harga saham. Hal ini berarti semakin tinggi nilai wajar asset maka cenderung dapat meningkatkan harga saham. Maka dapat disimpulkan bahwa mekanisme GCG memperkuatadanya hubungan antara relevansi nilai laba dengan harga saham atau dengan kata lain mekanisme GCG dapat memoderasi hubungan variabel tersebut.

Hipotesis 7 (H7.b)

Hipotesis 7 (H7.b) dalam penelitian ini diterima. Maka dapat disimpulkan bahwa mekanisme GCG dapat memoderasi adanya hubungan antara relevansi nilai wajar aset terhadap returnsaham.

\section{Hipotesis 8 (H8.a)}

Hipotesis 8 (H8.a) dalam penelitian ini diterimaHal ini berarti semakin tinggi nilai wajar liabilitas maka cenderung dapat menurunkan harga saham, Maka dapat disimpulkan bahwa mekanisme GCGdapat memoderasi adanya hubungan antara relevansi nilai wajar liabilitas terhadap harga saham walaupun secara negatif.

Hipotesis 8 (H8.b)

Hipotesis 8 (H8.b) dalam penelitian ini diterima. Hal ini berarti semakin tinggi nilai wajar liabilitas maka cenderung dapat menurunkan return saham. Hasil penelitian nilai wajar liabilitas keuangan menjadi signifikan, Hal ini berarti bahwa adanya moderasi mekanisme corporate governance membuat nilai wajar liabilitas keuangan berpengaruh.

\section{SIMPULAN}

Penelitian ini bertujuan untuk menguji relevansi nilai wajar aset dan liabilitas keuangan berdasarkan PSAK 55 (revisi 2014) terhadap harga saham dan return saham yang dimoderasi oleh corporate governance. Data yang digunakan dalam penelitian ini adalah laporan keuangan perusahaan perbankan yang terdaftar di Bursa Efek Indonesia dari tahun 2012 sampai dengan 2014. Penelitian ini telah menguji hipotesis dari variabel independen nilai buku, laba, nilai wajar aset dan liabilitas keuangan, variabel moderasi dewan komisaris independen, investor institusional dan komite audit serta variabel dependen harga saham dan return saham (model Ohlson 1995). Berdasarkan hasil penelitian ini, dapat ditarik beberapa kesimpulan sebagai berikut.

1. Pengukuran nilai buku per lembar saham berpengaruh terhadap harga saham.

2. Pengukuran nilai buku per lembar saham berpengaruh terhadap return saham.
3. Pengukuran laba per lembar saham berpengaruh terhadap harga saham.

4. Pengukuran laba per lembar saham berpengaruh terhadap return saham.

5. Pengukuran nilai wajar aset keuangan berdasarkan PSAK 55 berpengaruh terhadap harga saham.

6. Pengukuran nilai wajar aset keuangan berdasarkan PSAK 55 berpengaruh terhadap return saham.

7. Pengukuran nilai wajar liabilitas keuangan berdasarkan PSAK 55 berpengaruh secara negatif terhadap harga saham.

8. Pengukuran nilai wajar liabilitas keuangan berdasarkan PSAK 55 berpengaruh terhadap return saham namun secara negatif.

9. Mekanisme good corporate governance dapat memoderasi pengaruh pengukuran nilai buku terhadap harga saham

10. Mekanisme good corporate governance dapat memoderasi pengaruh pengukuran nilai buku terhadap return saham

11. Mekanisme good corporate governance dapat memoderasi pengaruh pengukuran laba terhadap harga saham

12. Mekanisme corporate governance dapat memoderasi pengaruh pengukuran laba terhadap return saham.

13. Mekanisme corporate governance dapat memoderasi pengaruh pengukuran nilai wajar aset keuangan berdasarkan PSAK 55 terhadap harga saham.

14. Mekanisme corporate governance dapat memoderasi pengaruh pengukuran nilai wajar aset keuangan berdasarkan PSAK 55 terhadap return saham

15. Mekanisme corporate governance dapat memoderasi pengaruh pengukuran nilai wajar liabilitas keuangan berdasarkan PSAK 55 terhadap harga saham.

16. Mekanisme corporate governance dapat memoderasi pengaruh pengukuran nilai wajar liabilitas keuangan berdasarkan PSAK 55 terhadap return saham.

Penelitian ini dapat memberikan implikasi bagi perkembangan teori, praktik, dan kebijakan, yaitu:

1. Implikasi Teoritis

Penelitian ini berhasil membuktikan bahwa pengukuran nilai buku (book value per share), laba (earning per share), nilai wajar aset keuangan dan nilai wajar aset liabilitas menurut PSAK 55 relevan untuk pengambilan keputusan investor yang 
tercermin dalam pengaruhnya terhadap harga saham danreturn saham.

\section{Implikasi Praktis}

Hasil penelitian ini dapat memberikan gambaran mengenai aplikasi pengukuran konsep nilai wajar laporan keuangan terutama perbankan yang mampu menciptakan relevansi nilai informasi keuangan akan membantu pengguna laporan keuangan, antara lain pihak (a) manajemen dalam menyusun transparansi laporan keuangan (b) auditor, sehingga memudahkan memberikan pendapat; dan (c) investor akan memperoleh informasi keuangan terkini yang lebih relevan dan komparabel sebagai dasar pengambilan keputusan atas investasi yang dilakukan.

3. Implikasi Kebijakan

Hasil penelitian ini dapat menambah literatur dan masukan mengenai penerapan nilai wajar di Indonesia dan dapat memberikan masukan kepada (a) Ikatan Akuntan Indonesia untuk mengimplementasikan adopsi IFRS yang lebih aplikatif dan sesuai dengan kondisi perbankan di Indonesia dengan memberikan informasi good governance yang lebih baik untuk meningkatkan kualitas standar akuntansi keuangan, serta meningkatkan transparansi perusahaan; (b) Bapepam untuk mengawasi publikasi laporan keuangan emiten, bahwa disesuaikannya PSAK dengan IFRS, berarti meningkatkan perlindungan bagi investor pasar modal karena laporan keuangan emiten yang dipublikasikan disajikan dengan standar akuntansi yang berkualitas tinggi, dan (c) Bank Indonesia untuk mengeluarkan Pedoman Good Corporate Governance Perbankan Indonesia yang lebih lengkap dan sebagai bagian tidak terpisahkan dari PedomanUmum GCG.

Penelitian ini memiliki beberapa keterbatasan dan sarannya antara lain:

1. Penelitian ini hanya meneliti industri perbankan yang terdaftar di Bursa Efek Indonesia dari tahun 2012-2014.

2. Penerapan nilai wajar terbatas untuk PSAK 55, sehingga terbuka kesempatan untuk melakukan penelitian atas penerapan nilai wajar selain PSAK 55 agar adopsi IFRS dapat diimplementasikan secara penuh sesuai harapan.

3. Proksi untuk mekanisme corporate governance dalam penenelitian ini hanya menggunakan persentase dewan komisaris indepeden, persentase investor institusional, dan jumlah komite audit sehingga belum menunjukkan mekanisme corporate governance secara keseluruhan.
Proksi untuk mekanisme corporate governance mungkin bisa menggunakan proksi lain seperti prinsip OECD (2008) yang mendukung agar praktik corporate governance dapat berperan efektif, dengan mencantumkan hak pemegang saham dan kesetaraan terhadap perlakuan terhadap pemegang saham sehingga akan memberikan hasil penelitian yang berbeda dan mungkin akan lebih baik selanjutnya dan dapat menggunakan indikator prinsip OECD (2008) yang diutamakan bagi perusahaan multinasional.

\section{REFERENSI}

Aboody, David; Barth, Mary E dan Ron Kasznik. 2006. Do Firms Understate Stock Option-Based Compensation Expense Disclosed under SFAS 123? Review of Accounting Studies 11, December 2006.

Alali, F.A.dan Foote, P.S. (2012). The Value Relevance Of International Financial Standards: Empirical Evidence in an Emerging Market. The International Journal of Accounting, $47,85-108$.

Anggraini, F. R. Retno. 2009. Nilai Wajar Saham pada Kualitas Laba. Manajemen dan Bisnis, Vol. 8 , No. 1

Anwar, Muhadjir. 2011. Karakteristik Perusahaan dalam Perspektif Mekanisme Corporate Governance dan Kinerja Perusahaan Go Public di Indonesia. Simposium Riset Ekonomi V.

Arifin, Zaenal. 2005. Teori Keuangan dan Pasar Modal. Edisi Pertama. Yogyakarta: Ekononisia.

Ball, Ray, S.P. Kothari dan Ashok Robin. 2000. The Effect of International Institutional Factors on Properties of Accounting Earnings. Journal of Accounting and Economics. Vol. 29, No. 1, p. 1-51

Barth, M. 1994. Fair Value Accounting: Evidence from Investment Securities and the Market Valuation of Banks. The Accounting Review 69, January 1994.

Barth, M., W. Beaver dan W. Landsman. 2001, The Relevance of the Value Relevance Literature for Financial Accounting Standard Setting: Another View. Journal of Accounting and Economics, 31: 77-104.

Barth, M. E., Landsman, W. R. dan Lang, M. (2008). International Accounting Standards and Accounting Quality. Journal of 
AccountingResearch, 46, 467-498.

Beaver, W. H. 2002. Perspective on Recent Capital Market Research. The Accounting Review 77(2): 453-474.

Bhat, Gauri. 2008. Impact of Disclosure and Corporate Governance on the Association between Fair Value Gains and Losses and Stock Return in the Commercial Banking Industry.

Bughsan. 2005. Corporate Governance, Earrning Management, and the Information Content of Accounting Earning: Theoretical Model and Empirical Test. Dissertation, unpublised. Bond University, Queensland, Australia.

Cahyonowati, Nur dan Rahmono, Dwi. 2012. Adopsi IFRS dan Relevansi Nilai Informasi Akuntansi. Jurnal Akuntansi dan Keuangan, Vol.14, No.2. November 2012.

Chrisnall, Paul. 2000. Fair Value Accounting - An Industry View. Financial Stability Review. December 2000.

Collins, Daniel W., Edward L. Maydew, dan Ira S. Weiss. 1997. Changes in the Value-Relevance of Earnings and Book Values Over th Past Forty Years. Journal of Accounting and Economics, Vol. 24: 39-67.

Daniri, M. Achmad dan Indirawati Simatupang. 2010. Saatnya Mengadopsi IFRS. Bisnis Indonesia. Edisi Minggu, 17 Oktober 2010.

Francis, J. dan Schipper, K. (1999). Have Financial Statements Lost Their Relevance? Journal ofAccounting Research, 37, 319-352.

Rahman, A.F. dan Norman, M.S. 2008. The effect of free cash flow agency problem on the value relevance of earnings and book value. Journal of Financial Accounting and Reporting. 75-90

Rahman, A.F. 2011. Masalah Keagenan Aliran Kas Bebas Manajemen Laba Dan Relevansi Nilai Informasi Akuntansi. Jurnal Ekuitas, Vol.15, No. 2 Juni 2011:232-246.

Gozali, Imam. 2011. Aplikasi Analisis Multivariate dengan Program IBM SPSS 19, Edisi 5. Badan Penerbit Universitas Diponegoro. Semarang

Handoko, Yohanes. 2010. Nilai Wajar (Fair Value). Handoko's Weblog.

Ikatan Akuntan Indonesia. 2009. Standar Akuntansi Keuangan Per 1 Juli 2009. Jakarta: Salemba Empat

Indriantoro, Nur dan Bambang Supomo. 2002. Metodologi Penelitian Bisnis untuk Akuntansi dan Manajemen. Yogyakarta. BPFE

Jensen, Michael C. dan William H. Meckling. 1976. Theory of the Firm: Managerial Behavior,
Agency Costs and Ownership Structure. Journal of Financial Economics, Vol. 3, No. 4, October 1976, p. 305-360.

Jogiyanto, H. M. 2000. Teori Portofolio dan Analisis Investasi. BPFE: Yogyakarta.

Jogiyanto, H. M. 2010. Teori Portofolio dan Analisis Investasi. BPFE: Yogyakarta.

Kaen, Fred. 2003. A Blueprint for Corporate Governance Strategy, Accountability, and the Preservation of Shareholder Value. AMACOM. USA.

Karampinis, N. dan Hevas, D. (2011). Mandating IFRS in an Unfavorable Environment: The Greek Experience. The International Journalof Accounting, 46, 304-332.

Kiswara, Endang. 2011. Nilai Relevan dan Reliabilitas Kegunaan-Keputusan Informasi Akuntansi menurut SFAC No. 2 dalam Penyajian Laporan Keuangan dengan Metode-Metode Pembebanan Pajak Penghasilan Berbeda.

Komite Nasional Kebijakan Corporate Governance. 2006. Pedoman Good Corporate Governance Perbankan Indonesia.

La Porta, R., Lopez-de-Silanes, F., Shleifer, A. dan Vishny, R. (1998). Law and Finance. Journalof Political Economy, 106(6), 1113-1155.

Landsman, W. R. 2007. Is Fair Value Accounting Information Relevant and Reliable? Evidence from Capital Market Research. Special Issue: International Accounting Policy 19-30.

Lev, Baruch and Paul Zarowin, 1999. The Boundaries of Financial Reporting and How to Extend Them. Journal of Accounting Research, Vol. 12, 312-316.

Lijing dan Bingjin Li. 2010. The Value-Relevance of Fair Value Measures for Commercial Banks: Evidences from the Chinese Bank Industries. International Research Journal of Financial and Economics. Issue 60

Liu, J., dan Liu, C. (2007). Value Relevance Of Accounting Information In Different Stock Market Segments: The Case of Chinese A-, Band H-shares. Journal of InternationalAccounting Research, 6, 55-81.

Naimah, Zahroh dan Siddharta Utama. 2006. Pengaruh Ukuran Perusahaan, Pertumbuhan dan Probabilitas Perusahaan terhadap Koefisien Respon Laba dan Koefisien Respon Nilai Buku Ekuitas: Studi pada Perusahaan Manufaktur di Bursa Efek Jakarta. Simposium Nasional Akuntansi 9, Padang, 23-26 Agustus 2006.

Nawangsasi, H., Rindarsih, A. dan Indra S. Giskha. 2010. Pro Kontra Fair Value, Kebaikan dan 
Keburukan Fair Value sebagai Dasar Pengukuran Aset. Seminar Akuntansi-Warsidi Blog.

Ohlson, J. (1995). Earnings, Book Values And Dividends in Quality Valuations. ContemporaryAccounting Research, 11, 661-688.

Ota, Koji, 2002. The Impact of Valuation Models on Value-Relevance Studies in Accounting: A Review of Theory and Evidence,www.ssrn.com, 1-36.

Pinasti, Margani, 2004. Faktor-Faktor yang Menjelaskan Variasi Relevansi-Nilai Informasi Akuntansi: Pengujian Hipotesis Informasi Alternatif, Simposium Nasional Akuntansi VII, 738-753.

Pressman, S. 2002. Lima Puluh Pemikir Ekonomi Dunia. PT Raja Grafindo Persada. Jakarta.

Rahmawati. 2005. Relevansi Nilai Earnings dengan Pendekatan Terintegrasi: Hubungan Nonlinier. JAAI, Vol. 9, No. 1.

Scott, W.R. 2009. Financial Accounting Theory. 4th ed. Pearson Education Canada Inc. Toronto.

Sekaran,Uma dan Roger Bougie. 2010. Research Method for Business: A Skill Building Approach, Fifth Edition. John Wiley \& Sons Ltd. UK

Song, C. Joon, Thomas, W. dan Han Yi. 2010. Value Relevance of FAS 157 Fair Value Hierarchy Information and the Impact of Corporate Governance Mechanisms. The Accounting Review. Vol, 85, No.4, p. 1375-1410.

Suharto, Hari. 2009. Bagaimana Menghitung Fair Value? Majalah Akuntan Indonesia. Edisi No. 16/Tahun III/2009.

Puspitaningtyas, Zarah.2012. Relevansi Nilai Informasi Akuntansi Dan Mamfaatnya Bagi Investor. Jurnal Ekonomi dan Keuangan, Vol.16,No.2. Juni 2012.

Wibisana, M. Jusuf. 2009. Dengan Fair Value, Laporan Keuangan Lebih Transparan. Majalah Akuntan Indonesia, Edisi No. 16/Tahun III/April2009

Wilopo. 2004. The Analysis of Relationship of Independent Board of Directors, Audit Committee, Corporate Performance, and Discretionary Accruals. Ventura. Vol.7, No. 1, April 2004

Wolk, H. I., J. L. Dood, dan M. G. Tearney. 2004. Accounting Theory: Conceptual Issues in a Political and Economic Environment. 6th ed. Thomson. South-Western.

Yan. 2010. Penerapan Akuntansi Nilai Wajar: Positif atau Negatif?. Yan's Blog.

Yuan, Zhou dan Jun, Ding. 2009. The Defect of Fair Value Under Global Financial Crisis. Journal of
Modern Accounting and Auditing, July 2009. Vol. 5, No. 7, p.52-55

Yusuf, Hamid. 2006. Jujur, Kita Belum Siap dengan Fair Value. Majalah Akuntan Indonesia. Edisi No. 16/Tahun III/April 2009.

Yusuf, Zen. 2010. Fair Value Accounting, Wajarkah bagi Keuangan Perusahaan?. Zen Yusuf Official Blog.

Zaini, Zulkifli. 2010. Lunchoen Speech. Disampaikan dalam Kongres XI Ikatan Akuntan Indonesia. Jakarta, 8 Desember 2010. 